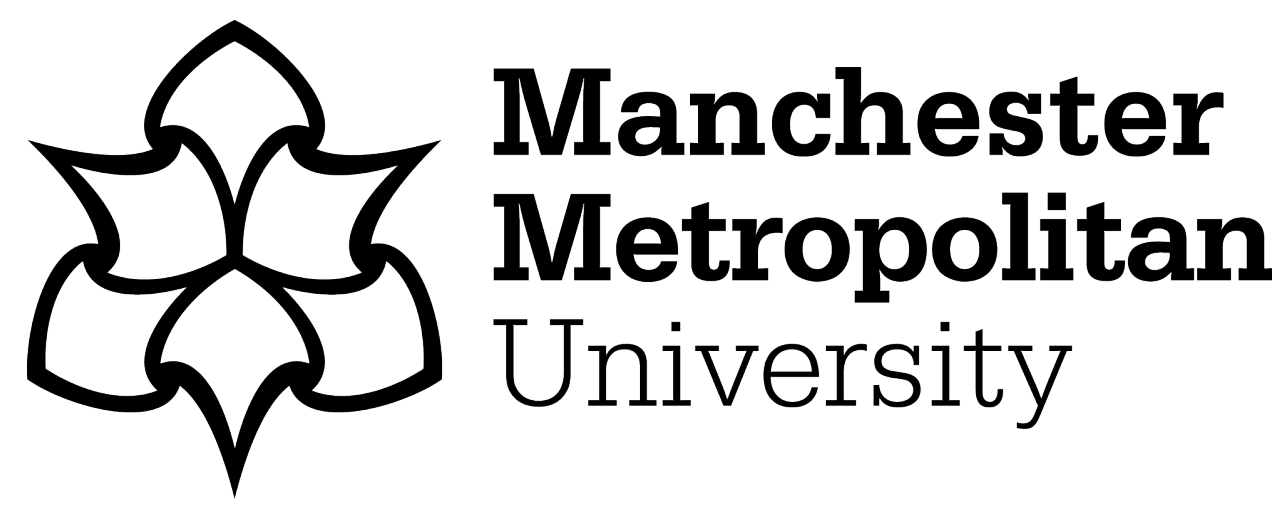

Fisher, JC, Lawthom, $\mathrm{R}$ and Kagan, $\mathrm{C}$ ORCID logoORCID: https://orcid.org/0000-0001-6015-6179 (2016) Delivering on the Big Society? Tensions in hosting community organisers. Local Economy, 31 (4). pp. 502-517. ISSN 0269-0942

Downloaded from: https://e-space.mmu.ac.uk/609615/

Version: Accepted Version

Publisher: SAGE Publications

DOI: https://doi.org/10.1177/0269094216650142

Please cite the published version 


\section{Delivering on the Big Society? Tensions in hosting community organisers}

Jenny Fisher, Rebecca Lawthom and Carolyn Kagan

Centre for Social Change and Well-Being

Manchester Metropolitan University

j.fisher@mmu.ac.uk

\section{Abstract}

The Big Society, including the community organising programme, was central to the UK Prime Minister, David Cameron's vision for a redefined relationship between state and society. Promising the devolvement of power to neighbourhoods and citizens. Community organising was funded by the Cabinet Office in 2011. Conceived of as a means of developing active engagement of communities and individuals to resolve the issues within deprived neighbourhoods. Manchester Metropolitan University hosted one of the first cohorts of community organisers working with a national organisation, Locality. This article provides a case study of 
a university community partnership centred on community organising. Drawing on narratives, we consider the tensions inherent in university hosting of community organisers, and the framing of the project as community organising as distinct from other forms of community practice.

\section{Key words}

Community organiser, Big Society, university, community

Community and engagement with communities continue to be a policy focus for governments in the United Kingdom (UK) steering initiatives and interventions particularly under the New Labour government through to the recent coalition government (Hancock et al., 2012). For the coalition government, the Big Society narrative and policy areas sought to encourage activism, and volunteering while aiming to change 'Broken Britain' (Clarke and Newman, 2012). The Big Society, whilst no longer a central policy focus of the current Conservative government, heralded a new approach to state funded and sanctioned community organising in England, UK. Community organising has not featured prominently within contemporary UK community practice and until the Big Society programme has not been funded through mainstream government (Bunyan, 2012). However, the Big 
Society programme that we discuss in this paper is not without historical antecedents in the United States and South America as we consider. Community organising's UK origins can be traced back to the practice of Neil Jameson, a Quaker social worker who was influenced by Alinsky, and established Citizens UK (see for example, Bunyan, 2010). Citizens UK's approach is centred around employing collective power for social change and justice (Chambers, 2003; Furbey et al., 1997), and they work with faith based organisations and communities across the UK including Manchester.

The context for this article was our involvement, as academics at Manchester Metropolitan University, in being selected as hosts of community organisers who were funded through the Big Society community organisers programme (Cameron, 2010). Universities in the UK continue to play a role in activities that contribute to the sustainable development of communities. HEFCE, the higher education funding body in the UK, has this vision:

universities and colleges are widely recognised as leaders in society's efforts to achieve sustainability-through the understanding, skills and attitudes that students gain and put into practice, through research and knowledge exchange, and through community involvement, as well as through their strategies and operations that bring all these together.

(HEFCE, 2014:4) 
We recognise that partnerships between universities and communities can take many forms, ranging from public engagement, volunteering, placements to service learning. When considering good practice, Kagan and Duggan (2011) assert that these partnerships are values led, should start with the concerns of the community, be reciprocal with attention to power issues and use a systems approach to support communities to be more resilient to change enhancing the well-being of those who reside there. As academics with a social justice value base, recognising knowledge and assets in communities can be straightforward, the difficult issue is how to enact this agenda, as we seek to explore here.

This paper addresses a need to theorise the tensions of university-led public engagement hosting of a government-funded programme which was overseen by a civil society organisation. Drawing on a case study, and a sensemaking narrative approach. the paper articulates the tensions of hosting and training community organisers within a university and the framing of the work as community organising. This is distinct from the expanding commentary and debate around the Big Society, and community organising (see for example, Bunyan 2012; Flinders and Moon, 2011; Taylor 2012). We commence with a brief outline of the Big Society community organisers programme to provide some context, and the 
rationale for and detail of the involvement of the University in the programme. Following a consideration of the case study methodology, we discuss the tensions experienced by a university in hosting community organisers, and explore the framing of the practice as community organising and some of the tensions we identified. As authors, we write from positionalities that are worthy of transparency. Whilst we are all based in academic settings, we have different locations and draw on a range of disciplines. $X X X X X X$ comes from an urban regeneration community development, and is steeped in locally and nationally based community practice, and both $\mathrm{XXXXX}$ and $\mathrm{XXXXX}$ work on community and social change projects based on collaborative, participatory ways (Kagan et al., 2011a). This affords more than an academic lens as we continue to be embedded in practice are committed to social change.

\section{Community organising}

Community organising is frequently linked to two key influences from the Global North, Saul Alinsky, and South, Paulo Freire (Ledwith,2005). Alinsky, working in disadvantaged neighbourhoods in Chicago, United States, based his much heralded and reproduced approach on power relations to address economic and 
social inequalities (Chambers, 2003). Collective power and local leadership is central to his 'home-grown' philosophy to neighbourhood social justice and change in what is called the Chicago model of community organising (Stall and Stoecker, 1998). Paulo Freire, a Brazilian academic and educationist, based his approach to community organising on animation, and informed praxis (Ledwith, 2005). He influenced informal education and community organising with a focus on raising the consciousness of disadvantaged individuals and communities enabling them to challenge the status quo and achieve social justice, alongside economic and social improvements in their lives. Freire asserts that overcoming oppression must be preceded by a recognition of the causes and an awareness of the injustice and oppression and states (Freire, 1996). Setting out a critical-consciousness-raising ideology in Pedagogy of the Oppressed (Freire, 1996), he continues to influence community practice across the globe.

Community organising in the UK can be traced to the efforts of Neil Jameson, a Quaker social worker who visited the USA in 1987 to carry out research on vandalism and self-help. He came into contact with the International Areas Foundation (IAF) originally set-up by Saul Alinsky, Influenced by the work of the 
IAF, and disillusioned by the church's efforts within the UK, to engage communities at the grassroots level and the prevalent ideology and hegemony of the ruling new right, which favoured regeneration over community welfare (Furbey et al., 1997), Jameson put into practice the organising techniques espoused by the IAF. Securing fiscal support from the Quaker backed Barrow Cadbury Trust (providing $£ 150,000$ core funding per annum) and the Anglican 'Church Urban Fund' (CUF), further visits to the USA followed and training was undertaken with the IAF, by senior UK religious figures. In 1988 the Citizen Organising Foundation (COF) was formed. This historical placing of the movement in the US, with its radically different welfare system, does not articulate a clear delineation from community development as such. Indeed academics and commentators have argued that there are overlaps between community development and organising (see for example Bunyan, 2010; Chanan and Miller, 2011; Taylor, 2012).

Returning to community organising, it was the flagship programme of the Big Society and indeed one of the most central aspects (Rowson et al., 2012). Launched in 2011, the four-year programme has $£ 15$ million funding from 2011 
until 2015. In 2010, David Cameron launched the programme as a 'neighbourhood army' that would be:

[t]rained with the skills they need to identify community leaders, bring communities together, help people start their own neighbourhood groups, and give communities the help they need to take control and tackle their problems. (Cameron 2010: online).

We now turn to a consideration of the background to the community programme organising programme, followed by the role of Manchester Metropolitan University and our rationale for involvement in the community organising programme.

\section{The Big Society community organising programme}

Following the launch of community organising, and a successful tender process, although in the midst of much criticism (see for example, Social Enterprise, 2011), the programme was contracted to a national civil society organisation, Locality. The organisation has a consortium of members who work at 'grassroots' level within neighbourhoods in England (Locality, 2011). Locality aimed to deliver a "home grown' modern version of community organisation for the twenty-first century. Their approach draws on the work of Alinksy (1989), Paulo Freire (1996) and Santos de Morais (Carmen and Sobrado, 2000) at grass-roots level (Taylor, 2012). Within the 
community organising programme, the five hundred full-time one year government funded community organisers were to work at neighbourhood level identifying local issues and leaders, and turn listening within neighbourhoods into action. Host organisations applied and were selected to host between one and five community organisers, and on commencement of the role, the organisers embarked on a training programme. We were asked to be a host in the pilot stage of the programme (ten hosts took part in the pilot stage) because of our existing relationships with community organisations, notably Marsh Farm, Luton, England. Further, XXXX had previously worked for the Community Development Foundation (a former national non-governmental organisation) and in this role has worked with the Development Trust Association (this organisation became Locality following a merger).

The majority of the training was provided by Locality's main partner in the programme, RE:generate Trust. This social action charity has developed an approach to community organising in England over ten years, and the training programme emphasises listening to people in the neighbourhoods, networking, dialogue and reflection. The training includes the aims and practice of community 
organising, listening to individuals and groups, reflective practice and issues of power and influence. It is based on RE:generate Trust's community animateur approach and works with a process of listening through to the formation of community holding teams (RE:generate Trust, 2012). We provide detail of the process as it was undertaken by the MMU community organisers. The listening process involves asking a series of questions that are detailed on a 'listening sheet'. These focus on an individuals' loves and concerns about the community, ideas for change and a vision for the future of the community ${ }^{1}$ The community organiser also asks the person if they have an ability or desire to be engaged in issues and voice their views, and then they would like to be involved in meeting others. Table 1 details the four stages of community organising as the community organiser begins with listening to individuals and this develops to group meetings, and then the establishment of a community holding team.

\section{Table 1 The Four Stages of Community Organising}

1 The process appears to relate to principles of appreciative enquiry (Cooperrider and Whitney, 1999) but this link is not formally acknowledged in the training. 


\begin{tabular}{|c|c|}
\hline Stage & Expected steps \\
\hline Stage 1 & $\begin{array}{l}\text { The community organiser listens to friends and family prior to } \\
\text { listening to individuals in neighbourhoods. All listenings are } \\
\text { recorded using 'listening sheets'. The community organiser finds } \\
\text { indiviudals to listen to via door-knocking or in publicly accessible } \\
\text { places (for example, cafes' pubs, markets). When a community } \\
\text { organiser undertakes a listening, they request contact details from } \\
\text { the individual. }\end{array}$ \\
\hline Stage 2 & $\begin{array}{l}\text { Through listening to people, the community organiser and the } \\
\text { indviduals involved identify other people who share similar } \\
\text { concerns or have ideas for the community. The community } \\
\text { organiser contacts these people and invites them to a 'house } \\
\text { meeting'. }\end{array}$ \\
\hline Stage 3 & $\begin{array}{l}\text { Those who share concerns or ideas meet at one of the individual's } \\
\text { homes or in a community venue. The listening process is repeated } \\
\text { by the group to identify an action plan. The community organiser } \\
\text { facilitates the 'house meetings'. }\end{array}$ \\
\hline Stage 4 & $\begin{array}{l}\text { The group form a community holding team and develop the } \\
\text { action plan. This can include ideas for community events, projects } \\
\text { or a campaign. }\end{array}$ \\
\hline
\end{tabular}

As academics with experience in working with communities, and through our professional networks, we were invited by Locality to be hosts for community organisers in the pilot stage as the programme was launched. Manchester Metropolitan University is the sole university to have hosted UK government funded community organisers and took up our role alongside Locality members, including Development Trusts across England. 


\section{The context of Manchester Metropolitan University and it's role}

Manchester is increasingly a city of diversity and inequality (Manchester City

Council, 2011), and Greater Manchester where we located our community organisers is part of the Northern Powerhouse launched in 2015 by the Chancellor of the Exchequer (Centre for Cities, 2015). The area of Greater Manchester has a population of 2.7 million people (GMPC, 2013). Recent census figures attest to the cosmopolitan nature of the city (143 languages are spoken) which enrich culture but bring other issues to the fore (ONS, 2012). The city and indeed the wider area continue to have a significant number of neighbourhoods recognised as highly disadvantaged areas (Manchester City Council, 2011). There is a large voluntary and community sector (Dayson et al., 2013), and in 2014, Greater Manchester became the first region to gain new powers over transport, housing, planning and policing. Further, in 2016, the region took control of combined health and social care budgets (GMCA, 2015).

Taking its role as a modern and global University seriously, Manchester Metropolitan University has a sustainable agenda and works in partnership with local communities, employers and businesses regionally, nationally and globally. 
The majority of students are drawn from the local area, and a key vision (to develop world-class professionals) feeds back into professional practice in the region. The university has campuses in Manchester city centre, south Manchester and in Crewe, Cheshire, and works in partnership with many voluntary and community networks and organisations in the region. Manchester Metropolitan University is part of the Manchester Corridor (a unique economic location in the heart of Manchester's knowledge economy).

On commencing our community organising hosting role, we recruited four community organisers who were from the university's recent alumni. Our hosting approach differed from other organisations in the pilot stage in four ways, for organisational and practical reasons. Firstly, we restricted the application process to students who had recently graduated from four under-graduate and postgraduate programmes with a focus on community practice, and secondly all were going on to study a postgraduate Youth and Community or Community Psychology programme (both with a community practice focus). We had agreed this with Locality, and the rationale was to drawn on recognised academic expertise around community psychology, engagement and practice. Other recruits across the 
programme had additional top up training elsewhere and in a dedicated block of time.

The second difference in our approach was to give the community organisers a choice as to where they located their community organising role. For other hosts, who operated within a defined geographical area, this choice was not an option. However, we recognised that the university is part of the wider community of Greater Manchester and Cheshire, and not located in one community. Further, we were aware of the costs of travel for the community organisers who were located across the region and wanted to minimise these given the salary level. Prior to the community organisers undertaking the training, we discussed possible locations for their work. Imagine is the learning and evaluation advisory team for the Community Organisers Programme. Their briefing paper, based on preliminary findings, identified value in the mixed approach of community organisers living in and outside of the host neighbourhoods (Imagine, 2013). However, for the first cohort there was significant discussion with Locality about whether community organisers should be 'parachuted in to' an area or already reside there. Our organisers all worked in or close to areas in which they lived or had previously undertaken 
community practice, but where they were not well-known, so as to avoid role tensions and blurring of boundaries between community organising and other kinds of community practice. They were located in an urban area close to the city centre, an urban conurbation to the north of the city within Greater Manchester, and a rural small town to the south of the region.

The third difference was our approach to the training, and the community organisers commenced a post-graduate programme alongside the RE:generate Trust led training. Finally, MMU directly employed its trainee organisers unlike most of the other hosts. Locality took the decision to employ the majority of community organisers in August 2011, and by this point we had already advertised the post on the previously agreed salary level. Changing the salary was not an option available. We now consider our methodological approach for this paper, which draws on a case study approach and the development of sensemaking narratives.

\section{Methodology}

The use of case studies can offer useful insights into experiences of delivering community based programmes particularly when they are located in real life 
encounters (Flyvberg, 2006; Stake, 1995). Flyvberg (2006: 241) asserts that 'the case study is a necessary and sufficient method for certain important research tasks in the social sciences, and it is a method that holds up well when compared to other methods in the gamut of social science research methodology.' Community organising and indeed community practice is a very human process which requires human approaches to knowing and with respect to case studies, Campbell (1975: 179,191) argues that:

After all, man is, in his ordinary way, a very competent knower and qualitative common sense knowing is not replaced by quantitative knowing ..... This is not to say that such common sense naturalistic observation is objective, dependable or unbiased. But it is all that we have. It is the only route to knowledge - noisy, fallible and biased thought it be.

Flyberg (2006) notes that expert learning occurs in context experience rich settings which cannot be encapsulated in rule bound stages. As others, we note that case studies can produce knowledge that is usefully context dependent and celebratory of alternative ways of knowing. Brown et al. (2008: 1035) assert that we need to pay attention 'to the narratives that actors tell about their work and self for both others and their selves.' During our role as hosts we sought to make sense of the work and our experiences (along with those of the community organisers) through 
sensemaking narratives, drawing on our ethnographic stories and narratives seeking to produce knowledge (Cunliffe and Coupland, 2012). Narratives are representations of the events that happen and a way of plotting the events and actions of practice (Riceour, 1984). Riceour (1984: 150) states:

A story describes a sequence of actions and experiences done or undergone by a certain number of people, whether real or imaginary. These people are presented either in situations that changes or as reacting to such change. In turn, these changes reveal hidden aspects of the situation and the people involved, and engender a new predicament which calls for thought, action, or both.

Findings for the case study were collected using a range of sensemaking methods and materials, including participant observation, informal time with community organisers, and immersion in key events and meetings (Stake, 1995). Each community organiser wrote weekly reflective diaries, and they were required to draw on their experiences, alongside academic learning in their post-graduate work. Two of the authors attended a three-day animation training, mirroring the training for the community organisers, and we convened six practice development days for the community organisers. As hosts, we undertook two visits to each area where the community organisers were based to either meet stakeholders or spend time and 'hang around' with the community organisers in their work. All of the stakeholders were aware of the researchers' status and we do not draw on 
conversations that the community organisers had with residents in the communities in which they were located. We took notes during events, meetings and attending and participating in the host training event, we used one word reminders which we then wrote up as observations and reflections (Crang, 1994). Being embedded in delivery and facilitation, we carved out space for joint reflection and analysis of our narratives and stories. This analysis draws on our experiences as actors in the process, reflecting our learning and position of boundary spanning civil society engagement, government delivery and university regulations. Here we focus on the edges or boundaries worthy of exploration, as we consider tensions in the hosting of community organisers within a university and the framing of the work as community organising.

\section{Tensions as university hosts}

In this section, we draw on our case study and narratives to consider tensions experienced as a university host within a civil society led and government funded programme of hosting and training community organisers. Universities are well placed to offer professional training where competencies and skills are regulated and standardised. Councils and colleges routinely participate and provide 
regulated frameworks to assess training for professional social workers or nurses. However, it was different, as here, community organising is not recognised professionally and the community organisers were trained by an external organisation in a process (outlined earlier).. They had autonomy and the training was not one with which we were familiar, despite some limited training. Whilst the approach has parallels with appreciative inquiry (Cooperrider and Whitney, 1999) and we had used previously used appreciative inquiry to work with community organisations, here the approach was whole community based, rather than located in an organisation or a project. The training with its positive tones could be argued as raising expectations about what could be expected from the project, for the community organisers, the hosts and more importantly, the community. Despite these differences and misgivings, we agreed that we would to support the community organisers in the methods they were being trained in and not resort to our tried and tested ways of working. The ongoing training that the community organisers received was predominantly be distance (online) and this curriculum was not explicitly shared with us as hosts, who did not have access to it. This presented possible contradictions over coverage and assumption that may have 
contrasted with the curriculum being offered in their postgraduate training (youth and community work and community psychology).

As hosts we were invited to an intensive training programme conducted by RE:generate over a residential 3 day event prior to recruiting the community organisers. In our experiences, the training did not make it clear how the process worked from listening to mobilisation and beyond, or how community organisers could learn to work in groups based on group experiential problems. Returning to Flyberg (2006), an issue with mobilising an 'off the shelf' approach to community organising was that the approach and method was a generalised set of precepts which were not context rich. Hosts were to support the community organisers but $R E:$ generate did the training and it was to RE:generate that they were supposed to look to get ideas when they were 'stuck'. The only way we as hosts knew what was being suggested was via the community organisers themselves, and we did not have access to the content of the training, the assignments COs were supposed to be doing or the feedback they got on their assignments. Inevitably, the RE:generate support was ignorant of local conditions and there were times when we found ourselves giving contradictory advice to community organisers. For 
example, we were unhappy with the door-knocking approach undertaken by a sole community organiser which contravened the university's risk assessment guidelines. Equally, sitting around in cafes (as was suggested by RE:generate) in some places would not be sensible given the fact that they can be 'controlled' spaces by having to pay to spend time there, or the owners may object to customers being questioned without prior agreement.

On some occasions we contacted RE:generate to discuss the advice they were giving to the community organisers and at other times to clarify for ourselves, details of the training and the expectations on the community organisers. The community organisers told us that at times it seemed they were caught between RE:generate, Locality and MMU, having to tell all parties what the others were saying. These tensions may have been specific to our hosting arrangements as we had a specific brief as educators and trainers for the course on which the COs were enrolled that was different from the RE:generate training.

We had pre-existing relationships with many of the agencies in the areas in which community organisers were working, and yet we were not encouraged by Locality 
to involve them in the project. This created difficulties as we could not, however, jeopardise existing networks, as they supported some of our other university work, particularly student placements from four different departments in the university. In this respect, we had a conflict of interest in being a host, with different sets of obligations towards agencies and voluntary and public sector bodies. Other hosts would also have had competing obligations towards local bodies as they tried to stick to the new CO programme. Imagine (2013: 2-3) recognises the risks to reputation and relationships that might be involved with the new programme and note that 'local history and experience needs careful handling'.

An example of this risk occurred when one of the community organisers experienced some conflict following local stakeholders enquiring why she was 'working on their patch.' We attended a meeting with the local stakeholders, the community organiser and a representative from Locality. The key issue was that they wanted to community organiser to build on their existing community engagement work, work in a defined area and include them in any discussions. The stakeholders informed us that they had already undertaken community engagement activities and no further consultation was needed. Further, the local 
voluntary organisation was concerned that the community organiser would establish groups without the necessary support to sustain them (a valid point). When Locality realised the pressure being put upon community organisers from the stakeholders, they contacted the civil servants responsible for implementing community organising with the Office for Civil Society, who wanted to secure ministerial and local Member of Parliament involvement. At the time we noted that the mobilising of top-down channels of power by Locality was in direct contrast to the community organising programme being a new way of working that avoided (even challenged or undermined) traditional power structures.

RE:generate Trust considered that government interference was inappropriate and encouraged the community organisers to resolve the situation supported by them as training providers, and to stick to the set model that they trained the community organisers in. This led to a conflict of interest for ourselves as colleagues in other departments at the university were working proactively with the same stakeholders on other projects. Further, this intransigent adherence to the model did not help as it favoured existing agencies and sources of working in the early stages, in favour of listening to local people and moving towards a situation where they identified 
areas for action. It was this exclusion in the first place that had precipitated the concerns, and other stakeholders were genuinely bemused as to why there should be a way of working that did not fit or take account of their established methods.

The university had developed good working relationships within another area over a significant time-period, in which a community organiser was working. We were keen to maintain these links with the local community and voluntary sector and local authority stakeholders, which included student placement opportunities and placement support. In supporting the community organiser, the chair of the local community association was keen to draw on the organising work to inform the work of the association. At the time, the government had introduced a parallel programme (Community First Fund) in some local areas to community organising including funding to support community projects. Local organisations were required to make decisions on local spending priorities within a short timescale and there was no public information about how the two programmes would relate to each other. 
The community association invited the community organisers to attend local meetings and contribute to local knowledge through sharing the issues they were hearing about through their 'listening' activities. However, the community organisers had been told by Locality and RE:generate Trust that they could not share the information as it belonged to the community and would be shared with a community holding team when established (stage four of the listening process). The community association persisted in trying to encourage collaborative working with the community organisers, and through our role as hosts with existing good working relationships in the area, we managed to work to a compromise. The logic of the organising process needed to be made more transparent.

In the same area, one of the community organisers had been listening to women at a local mosque, people that the community organisation had found it difficult to engage with. Again, she was asked for the information by local stakeholders, and raised the issue with the training provider following the involvement of the local Member of Parliament. By April 2012, new guidance was released by Locality, contradicting their previous position of not co-operating with the Community First process. Once again, the power (or threat of power) of the state had been 
mobilised to support the position of the community organisation, thus activating the same power channels that the community organising process was supposedly side-stepping. We now turn to tensions experienced and our approach to understand in the framing of the project as community organising as distinct from other forms of community practice.

\section{Community organising or community practice}

Some of the tensions in the way the project was set up as community organising and operated were evident in our collective experiences of the project and indeed in the academic commentary (see for example Bunyan, 2012; Chanan and Miller, 2011). One of the criteria for judging the applicants to the Government's tender for the Community Organising project was 'adherence to the principles of [Paulo] Freire and [Saul] Alinksy' (Locality, 2011: online). From the outset, we felt some disquiet with these intentions, coming as they were from a right wing coalition government, implementing the programme in a top -down fashion (Kagan et al., 2011b; King et al., 2010). Freire (1996) advocated a form of critical pedagogy, a way of working with disadvantaged and marginalised people and communities that had an explicit value base and goal of social transformation. Central to the process 
is conscientisation, the growing understanding of power and powerlessness that arises from action. The community organisers programme had no explicit value based other than to empower people, and the organisers were expected to listen to anyone, and nothing was vetoed. We and our organisers were experienced community practitioners. Our approach had synergies with the community organiser programme but with some important differences. We (and the programme) worked in areas of multiple deprivation and marginalisation; worked in ways to build on people's strengths and commitments and worked with an explicit (albeit with a different focus) value base. For the community organisers, their values including promoting equality was important, and we sought to work in ways that built on existing networks and resources and identified relevant positive and negative stakeholders from the outset. A key to our working was to identify and remove potential blocks to action. Furthermore, a core aspect of our approach was to find ways of working in participation, gaining trust and only then being able to work with local people to identify their priorities and concerns, challenging these where necessary in order to facilitate the identification of ideological features of local issues (see Gilchrist and Taylor 2011; Kagan, et al., 2011b). The RE:generate Trust process commenced with individuals, listen to them carefully and identify 
where there might be common interests for action with others. No ideas were vetoed and it was not the CO's place to challenge ideas. Returning to Freire (1996), problematisation is central and we were unable to see evidence of issues raised by individuals (for example, migration) being problematised.

Deideologisation, where marginalised people are helped to understand their social reality (not the view of hegemonic government) another aspect of Freirean methods was absent from the organisers' training in our view.

When the community organising programme was launched, there was debate about the relevance of Alinsky's Rules for Radicals, the foundation of his approach. Zacharzewski (2011) summarised a blog debate catalysed by Tessy Britton who suggested that Alinsky's 'rules' predicated as they are on conflict and confrontation, are outmoded: she argued instead for a collaborative approach to community mobilisation more akin to modern community practice that was inclusive. Another contributor to the debate, highlighted the problem that remained, even if the Alinskian approach was modified:

There is an elephant in the room here, though, and its name is equality. More often than not those without political, economic or social power are encouraged to transform the way they operate in order to fit the values and objectives of those with power (Dobson 2011: online). 
It was evident to us and the community organisers, that the Alinskyan element of the programme was becoming less visible in the training, as the approach shifted towards working with existing stakeholders and not challenging those in power. In mobilising the required five hundred strong 'army' of community organisers, contextual understanding and radical approaches were less visible in the standardised training programme. The inclusive approach to building a community holding team (based on personal interest rather than shared values) alongside the overt transparency to identify issues for teams to work on highlights the conservative orientation. We questioned how such an approach would work to challenge power structures. Moreover, the community organisers were required to recruit unpaid volunteers to mobilise and change their communities, and while recognising the value of volunteering, issues emerged around inequity in roles and pay. It was difficult for the community organisers hosted at Manchester Metropolitan University to recruit volunteers and those recruited often left quickly as they were using the opportunity to move into paid work.

The community organising approach espoused by the Big Society programme is at odds with other prevalent models of partnership working and community 
development (Chanan and Miller, 2011). The lack of communication vis a vis the State and existing practitioners, in outlining the fundaments of the community organising approach, only served to antagonise the relationships formed with community organisers, positioning them as 'uncooperative disruptors'. It is evident that the disruption caused to the existing ways of doing community work served to challenge the efficacy of the existing system (for example, in gaining access to Muslim residents in one area that had proved problematic), providing evidence that alternative practice could supplement their ways of working. However, the insistence of the community organising programme not to share information and exchange community intelligence likely undermined its real value to contribute to on-going community work.

By starting fresh within community settings, potentials to build on work already undertaken and leveraging existing social capital and community memory were not harnessed. This led to actors within the existing system decrying the duplication of efforts and consultation processes, and bemoaning lost opportunities for collaborative working and knowledge exchange. Further, being unable to work within existing practice lead to the community organiser's isolation as a 'lone 
worker' within an area. It should be noted as a separate issue that community organisers frequently spoke to us of isolation and their concerns around working on their own in communities.

The difficulties experienced on the ground between community organisers and other community practices shed light on the contradictory and confused implementation of the Coalition's Localism agenda (Westwood, 2011). New Labour's engagement and empowerment policies, worked to catalyse social capital and harness local knowledge to enhance the quality of policy provision and service delivery (Imrie and Raco, 2003). In contrast, commentators argue the Big Society's mistrust of local government and the cutting out of local partnerships is likely to undermine community work and activism rather than liberate it (Lowndes and Pratchett, 2012). We feel that the silo practices enforced by the CO programme, vis-à-vis existing community partners, are an exemplar of this undermining in action. In creating a new system which rubbed up against existing systems, competition and conflict were evident, not co-operation.

With reference to other historical examples of community organising in the UK, it has been suggested that the core activity, the one-to-one listening and group- 
based activism, have provided radical opportunities to invigorate and mobilise communities at the grassroots level (see for example, Furbey et al., 1997, Warren, 2009). In discussing these potentials, it has been suggested that these types of encounters have cultivated a third space of political life more readily accessible to communities (Bunyan, 2012). This space sits between the micro level of personal issues and the macro level of public interests and allows political action to result directly from personal engagement with issues that places an onus on powerbased over needs-based approaches, reasserts political activity and affords opportunities to talk back to power (Bunyan, 2012). It is possible that that the listening pathway articulated in the Big Society model may foreground individual concerns at the expense of wider projects centred on social justice. We have noted elsewhere the limitations of this project to relate to the citizenship agenda (Fisher et al., 2014)

The Big Society community organising process assumed newness - organisers mobilise through listenings and generate new connections. This approach may be criticised in the same way that regeneration professionals often do not live in the 
communities they are working with (Hoggett, 1997). Community organisers with no prior knowledge of a community may unknowingly making connections already in place or upset existing structures and relationships (as our examples showed earlier). Community development approaches to $\mathrm{CO}$, however, work explicitly in engaging and levering social capital (Gilchrist 2009; Gilchrist and Taylor 2011). A community development worker is engaged in supporting people to make new connections with existing structures, outside of the immediate community. This bridging capital is significantly important for the community members to build alliances outside of the community, yet with understandings of history and context.

The challenges posited to effective community engagement, through the isolated practices of community organisers, were compounded by difficulties in the responsibilities placed on organisers, as to how they engaged and worked with people in community settings. The key feature of community organising, the oneto-one listening, is central to both Big Society community organising and other existing UK based community organising initiatives such as that promoted by Citizens UK. They differ in that the former would seem to privilege individual needs, 
whereas the community articulated in the Citizens UK model, looks to build bridges between existing groups and institutions.

Within the Big Society model, the community organiser is fore-fronted within a complex system. The community organiser begins the process listening to individuals and then moves to group-based practice, and ultimately to locality wide organising. Our experience was that the one-to-one work with individuals was more successful than the group work. The process of working in a group was difficult, not least due to the unwillingness of people to open their homes to others. Some individuals expressed a wish to work alongside the community organisers in a volunteer role. However, this was frequently short-lived as people moved onto employment elsewhere or struggled with the process of listening to strangers.

\section{Conclusions}

As we stated earlier, this paper is based on a case study approach (Flyvberg, 2006) in which we draw on sensemaking narratives collected through ethnographic practice. We are cognisant that this is our particular experience and is related to our unique position as hosts (which takes time) and as educators with values. 
From this perspective of delivery and drawing on more radical knowledge of organising, we have made sense of our particular role within the context.

Whilst the initial hosting programme was only a year in duration, which precludes a longitudinal analysis of the development of these concerns into programmes of action, it is difficult to conceive that such starting points could flourish into campaigns aimed at challenging power. Rather, given the previously cited issues of access and resources, it is probable that any sustained action would likely be in the form of individualistic 'pet' projects mobilised by those volunteers with the socioeconomic, psychological and social resources, rather than those most in need.

In 2012, Locality informed the pilot hosts that the coalition government had agreed to further funding for the programme. We were to be given support from Locality in identifying match-funding for the $£ 15,000$ government grant for each community organiser to continue in employment for a further year. By this point, one of the MMU organisers had left our employment for personal reasons. One organiser informed us that she did not wish to continue in the role. We attempted to support one of the remaining organisers in seeking a new host, located in the area where she lived and had previously worked in youth service provision. She is now 
employed by a new host, and identifying the match funding has been difficult, and a lengthy process. The fourth community organiser has established a social enterprise and is now hosting community organisers. Principles of good community engagement will continue to be of strategic importance for universities. However, these spaces need continual reflection as the economic, policy and social landscape shift. Hosting activity requires clearer alignment of agendas and transparency, something we have attended to in this paper.

\section{Acknowledgements}

We are grateful to the community organisers who were hosted by Manchester Metropolitan University between 2011 and 2012 for their contributions to the case study.

\section{References}

Alinsky S (1989) Rules for radicals. London: Vintage Books.

Brown A D, Stacey P and Nandhakumar J (2008) Making sense of sensemaking narratives. Human Relations 61(8): 1035-1062. 
Bunyan P (2010) Broad-based organizing in the UK: reasserting the centrality of political activity in community development. Community Development Journal, 45(1): 111-127.

Bunyan P (2012) Partnership, the Big Society and community organizing: between romanticizing, problematizing and politicizing community. Community Development Journal, 48(1): 119-133.

Cameron D (2010) Big Society Speech July 2010. Available at: http://www.number10.gov.uk/news/speeches-and-transcripts/2010/07/big-societyspeech-53572 (accessed October, 2012).

Campbell DT (1975) Degrees of freedom and the case study. Comparative Political Studies, 8(1): 178-191.

Carmen R and Sobrado M (2000) A Future for the Excluded. Job Creation and Income Generation by the Poor: Clodomir Santos de Morais and the Organization Workshop. London: Zed Books Limited 
Centre for Cities (2015) Northern Powerhouse factsheet. Key figures on the city regions in the Northern Powerhouse. London: Centre for Cities.

Chanan G and Miller C (2011) The Big Society and public services: Complementarily or erosion? Brighton: Paces.

Chambers E (2003) Roots for radicals: organizing for power, action, and justice. London: Continuum International.

Clarke and Newman J (2012) The alchemy of austerity. Critical Social Policy 32(3): 299-319.

Cooperrider D L and Whitney D (1999) Appreciative inquiry. San Francisco: BerretKoehler. 
Crang P (1994) It's showtime: On the workplace geographies of display in a restaurant in south-east England. Environment and Planning D: Society and Space 12(6): 675-704.

Cunliffe A and Coupland C (2012). From hero to villain to hero: making experience sensible through embodied narrative sensemaking. Human Relations 65(1): 63-88.

Dayson C Eadson E Sanderson E and Wilson I (2013) City of Manchester: State of the Voluntary Sector 2013. Sheffield: Centre for Regional Economic and Social Research, Sheffield Hallam University.

Dobson J (2011) Community Organisers: collaborators or prophets? Living with rats: Exploring Better ways to Live and how to Create Better places to Live in. Available at: http://livingwithrats.blogspot.com/2011/04/community-organiserscollaborators-or.html (accessed January, 2014). 
Fisher J Lawthom R and Kagan C (2014) Revolting talks of migrant workers and community organisers - a UK Community Psychology perspective. Australian Community Psychologist 26(1): 37-50.

Flinders M \& Moon DS (2011) The problem of letting go: The 'big society', accountable governance and 'the curse of the decentralizing minister'. Local Economy 26(8): 652-662.

Flyvberg B (2006) Five Misunderstandings About Case-Study Research. Qualitative Inquiry 12(2): 219-245.

Freire P (1996) Pedagogy of the Oppressed. London: Penguin.

Furbey R Else P Farnell R Lawless P Lund S and Wishart B (1997) Breaking with tradition? The Church of England and community organising. Community Development Journal 32 (2): 141-150. 
Gilchrist A (2009) The well-connected community: a networking approach to community development. $2^{\text {nd }}$ ed. Bristol: The Policy Press.

Gilchrist A and Taylor M (2011) The Short Guide to Community Development. Bristol: Policy Press.

GMPC (Greater Manchester Poverty Commission) (2013) Greater Manchester Poverty Commission Recommendations Report. Manchester: CLES.

GMCA (Greater Manchester Combined Authority) (2015) Taking charge of our Health and Social care in Greater Manchester. Manchester: GMCA. Available at: http://www.gmhsc.org.uk/assets/GM-Strategic-Plan-Final.pdf (accessed March 2016).

Hancock L Mooney G and Neal S (2012) Crisis Social Policy and the Resilience of the Concept of Community. Critical Social Policy 32(3): 343-364. 
HEFCE (Higher Education Funding Council for England) (2014) Sustainable Development in higher education. HEFCE's role to date and a framework for its future actions. Available at: http://www.hefce.ac.uk/media/hefce/content/pubs/2014/201430/HEFCE2014_ 30.pdf (accessed March 2016)

Hoggett, P. (1997) Contested communities: experiences, struggles, policies. Bristol: The Policy Press.

Imagine (2013) Locally rooted: Hosting community organisers Available at: http://www.cocollaborative.org.uk/resource/locally-rooted-hosting-communityorganisers (accessed February, 2013).

Imrie R and Raco M (2003) Urban renaissance?: New Labour, community and urban policy. Bristol: The Policy Press. 
Kagan C and Duggan K (2009) Creating Community Cohesion. The power of using innovative methods to facilitate engagement and genuine partnership. Social Policy and Society 10(3): 393-404.

Kagan C Burton M. Duckett, P Lawthom, R and Siddique A (2011a) Critical community psychology. Oxford: Wiley-Blackwell.

Kagan C Duckett P and Lawthom R (2011b) Community activism and community organising in the UK: rhetoric, seduction and danger for community psychology. Paper presented in C. Kagan, M. Carmona and R.D. Fernández (Conveners): Symposium- Community Action and Public Policies within a multilevel approach. $8^{\text {th }}$ European Community Psychology Conference, York.

King E Roberts L Toynbee M (2010) The New 'Neighbourhood Army': The Role of Community Organising in the Big Society. London: Office for Public Management.

Ledwith M (2005) Community development: a critical approach. Bristol: The Policy Press. 
Locality (2011) Tender to provide a National Partner for the Community Organisers Programme. Available at: http://locality.org.uk/wp-content/uploads/Locality-COweb-25052011.pdf (accessed March 2012).

Lowndes V and Pratchett L (2012) Local government under the coalition government: austerity, localism and the 'Big Society'. Local Government Studies 38(1): $21-40$.

Manchester City Council. (2011) Indices of multiple deprivation 2010. Manchester: $\begin{array}{llll}\text { Manchester } & \text { City } & \text { Council. }\end{array}$ www.manchester.gov.uk/download/downloads/id/16070/f1_index_of_multiple_depri vation_2010_- manchester.pdf $+\& \mathrm{~cd}=1 \& \mathrm{hl}=\mathrm{en} \& \mathrm{ct}=\mathrm{clnk \& gl=us} \quad$ (accessed March 2016) 
Office for National Statistics (ONS) (2012) 2011 Census. London: Office for National Statistics. Available at: http://www.ons.gov.uk/ons/publications/index.html (accessed January 2013).

RE:generate Trust (2012) Root Solutions, Listening Matters Available at: http://issuu.com/regeneratetrust/docs/guide to $r$ s $/ m 2011$ ?mode=window (accessed $10^{\text {th }}$ February 2014)

Ricoeur P (1984). Time and Narrative, Volume 1. Translated by K.McLaughlin and D. Pellauer. Chicago: Chicago University Press.

Rowson J Kálmán Mezey M and Dellot B (2012) Beyond the Big Society: psychological foundations of active citizenship London: Royal Society for the Encouragement of Arts. Available at: http://www.thersa.org/_data/assets/pdf_file/0004/565411/NEW-NEW-COVERBeyond-Big-Society-report-V10.pdf (accessed February 2013). 
Social Enterprise (2011) Community organisers - conflict, collaboration, communication and consensus. Available http://www.socialenterpriselive.com/your-blogs/item/community-organisers\%E2\%80\%93-conflict-collaboration-communication-and-consensus (Accessed on February 2013].

Stake R E (1995) The art of case study research. Thousand Oaks, CA: Sage.

Stall S and Stoecker R (1998) Community organizing or organizing community? Gender and the Crafts of Empowerment. Women's Studies 12(6): 729-756.

Taylor M (2012) Community organising and the Big Society: is Saul Alinsky turning in his grave? Voluntary Sector Review 22(2): 257-264.

Warren M (2009) Community organizing in Britain: the political engagement of faith-based social capital. City and Community 8: 99-12. 
Westwood A (2011) Localism, social capital and the Big Society. Local Economy 26(8): 690-701.

Zacharzewski A (2011) Democracy for New Radicals. Available at: http://www.demsoc.org/blog/2011/05/03/democracy-for-new-radicals (accessed March 2014). 